\title{
Agranulocytosis associated with sulphasalazine therapy
}

\author{
P. COCHRANE \\ M.D., M.R.C.P., D.C.H., D.R.C.O.G. \\ P. AtKInS \\ M.S., F.R.C.S. \\ S. EhSANUllah \\ M.B., B.S., D.T.M.\&H., D.C.P., D.Path. \\ Walton Hospital, Liverpool
}

\begin{abstract}
Summary
A case report of a patient with agranulocytosis associated with sulphasalazine therapy is described. Recovery followed supportive therapy and withdrawal of the drug. Investigations including tests for leucocyte antibodies, the presence of which might have suggested an immunological cause for the drug reaction, were negative; an acetylation study, however, characterized the patient as a 'slow' acetylator phenotype, suggesting that the drug reaction was more likely to have been toxic in nature. It is suggested that acetylation studies be performed in patients who have previously shown serious side effects to sulphasalazine to assess the incidence of 'slow' acetylators.
\end{abstract}

\section{Introduction}

Sulphasalazine is now well established as an effective drug in the treatment of ulcerative colitis (Misiewicz et al., 1965). Minor side effects are common; variously reported as between 9 and $60 \%$ Collins, 1968 and Lennard-Jones et al., 1960 noted that more than half of their patients receiving $4 \mathrm{~g} /$ day had anorexia, nausea and malaise. Serious haematological complications are uncommon and agranulocytosis is rare (Collins, 1968). The sulphapyridene component of sulphasalazine is thought to be responsible for the side effects. Two mechanisms have been postulated, either that the sulphapyridene has a direct toxic effect, or that it brings about an immunological response (Evans \& Ford, 1958). Here we describe a case report of a patient who developed agranulocytosis following sulphasalazine and the investigations performed to elicit the nature of this drug reaction.

\section{Case report}

A 70-year-old female was first seen at Walton Hospital, Liverpool, on 1 February 1972, complaining of passing blood and mucus per rectum for 3 months. The faeces were loose and the bowels moved up to twenty times a day. She was otherwise well and her weight had remained steady. Her previous history was unremarkable, apart from a history of contact eczema to rubber, flour and nickel. Sigmoidoscopy showed a granular mucosa with blood and mucus extending throughout the rectum and sigmoid colon, which was typical of ulcerative colitis. A biopsy taken at $20 \mathrm{~cm}$ showed a densely inflamed mucosa, compatible with ulcerative colitis. A barium enema on 24 February showed no abnormality. The haemoglobin, white cell count and film were normal at this time. Codeine phosphate $30 \mathrm{mg}$ twice daily was prescribed initially, but as the diarrhoea persisted, sulphasalazine $1 \mathrm{~g}$ four times daily was started on 29 February. After taking three sulphasalazine tablets her eyes became swollen; she temporarily stopped this treatment and the swelling rapidly settled. When admitted for assessment on $13 \mathrm{March}$, her bowels were open four times per day and sigmoidoscopy showed some improvement, although a patchy granular proctocolitis was still present. Sulphasalazine was therefore restarted and there was no further swelling of her eyes.

The patient was seen on 18 April when the diarrhoea was well controlled, but she complained of anorexia, marked lassitude and weight loss. The sulphasalazine therapy was therefore stopped. These symptoms were associated with a neutropenia (WBC $1900 / \mathrm{mm}^{3}$ ), although this result was not known until she was admitted to hospital 6 days later. By this time she had developed a patchy pustular rash affecting the face and limbs. In addition she complained of rigors and abdominal cramps. On examination, she was dehydrated with a rapid tachycardia and a temperature of $101 \cdot 2^{\circ} \mathrm{F}$. Investigations performed at this time showed that the white cell count had fallen to $900 / \mathrm{mm}^{3}$-made up entirely of lymphocytes and monocytes. The haemoglobin was $10 \mathrm{~g} / 100 \mathrm{ml}$ and the platelet count was normal. Escherichia coli were cultured from the blood and Staphylococcus aureus from the skin pustules. Examination of the bone marrow showed large numbers of myelocytes and metamyelocytes, but no mature granulocytes ('maturation arrest')—red cell 
formation was normal (Fig. 1). Vigorous treatment was instituted; this included gentamycin $(60 \mathrm{mg}$ i.v., 8 hourly), cloxacillin ( $500 \mathrm{mg}$ i.v., 6 hourly), hydrocortisone (100 mg i.v., 6 hourly) and $\gamma$ globulin (500 mg i.m. Stat.). Over the next few days the patient's condition improved dramatically and the blood count returned to normal (Fig. 2). Later, two abscesses on the nose and one on the right leg were incised, but otherwise the patient made an uneventful recovery. A second bone marrow examination on 9 May was entirely normal. In addition to the regular blood counts, the following investigations were also performed at this stage. Coombs' test, negative; serum bilirubin, $1.0 \mathrm{mg} / 100 \mathrm{ml}$; reticulocyte count, $1 \%$; urinary urobilinogen, no excess; Heinz body test, negative; serum folate, $5 \cdot 2 \mathrm{mg} / 100 \mathrm{ml}$; vitamin $\mathrm{B}_{12}, 1200 \mu \mathrm{g} / 100 \mathrm{ml}$; serum iron, $72 \mu \mathrm{g} / 100 \mathrm{ml}$; total iron binding capacity, $330 \mu \mathrm{g} / 100 \mathrm{ml} ; \%$ saturation, $22 \%$; RA and LE latex, negative; ANF, negative; blood urea, $26 \mathrm{mg} / 100 \mathrm{ml}$; serum sodium, $127 \mathrm{mEq} / \mathrm{l}$; serum chloride, $102 \mathrm{mEq} / \mathrm{l}$; and serum potassium, $3 \cdot 1 \mathrm{mEq} / \mathrm{l}$. Total plasma proteins, $6 \cdot 3 \mathrm{~g} /$ $100 \mathrm{ml}$; albumen, $3.0 \mathrm{~g} / 100 \mathrm{ml}$; total globulin, $3.3 \mathrm{~g} /$ $100 \mathrm{ml} ; \alpha_{1}$ globulin, $0.3 \mathrm{~g} / 100 \mathrm{ml} ; \alpha_{2}$ globulin, $0.9 \mathrm{~g} /$ $100 \mathrm{ml} ; \beta$ globulin, $1.0 \mathrm{~g} / 100 \mathrm{ml}$; and $\gamma$ globulin, $1 \cdot 1 \mathrm{~g} / 100 \mathrm{ml}$.

Three days later a screening test for cytotoxic (Terasuki \& McClennand, 1964) and leucoagglutinat-

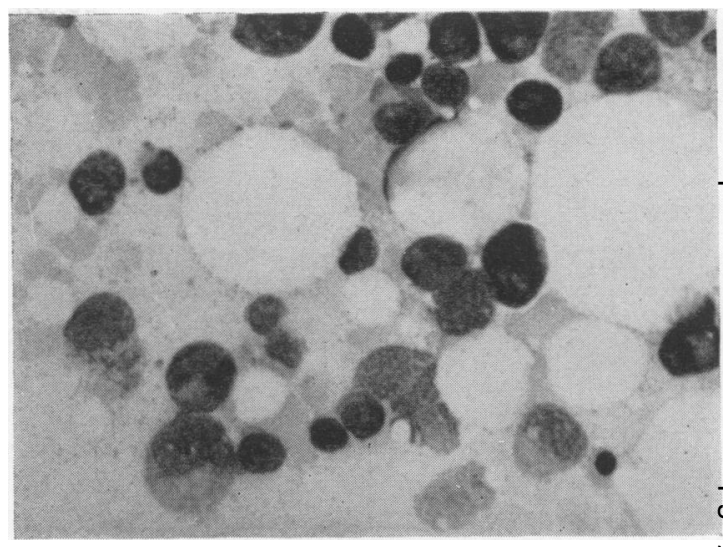

Fig. 1. Sternal marrow of patient with agranulocytosis associated with sulphasalazine therapy, showing excess myeloid precursors ('maturation arrest') but no mature polymorphs. Red cell formation is normal.

ing antibodies (Walford, 1960) was negative. Sub-오 sequently, after recovery of the white cell count, an $\vec{C}$ isoniazid acetylation test (Evans \& White, 1964) was performed; this characterized the patient as a 'slow' phenotype. (The patient was fasted for $12 \mathrm{hr}$; t 3 6 a.m. a single dose of isoniazid was taken. The⿻ blood levels of isoniazid were: 8 a.m., $13 \cdot 24 \mu \mathrm{g} / \mathrm{m} ;$

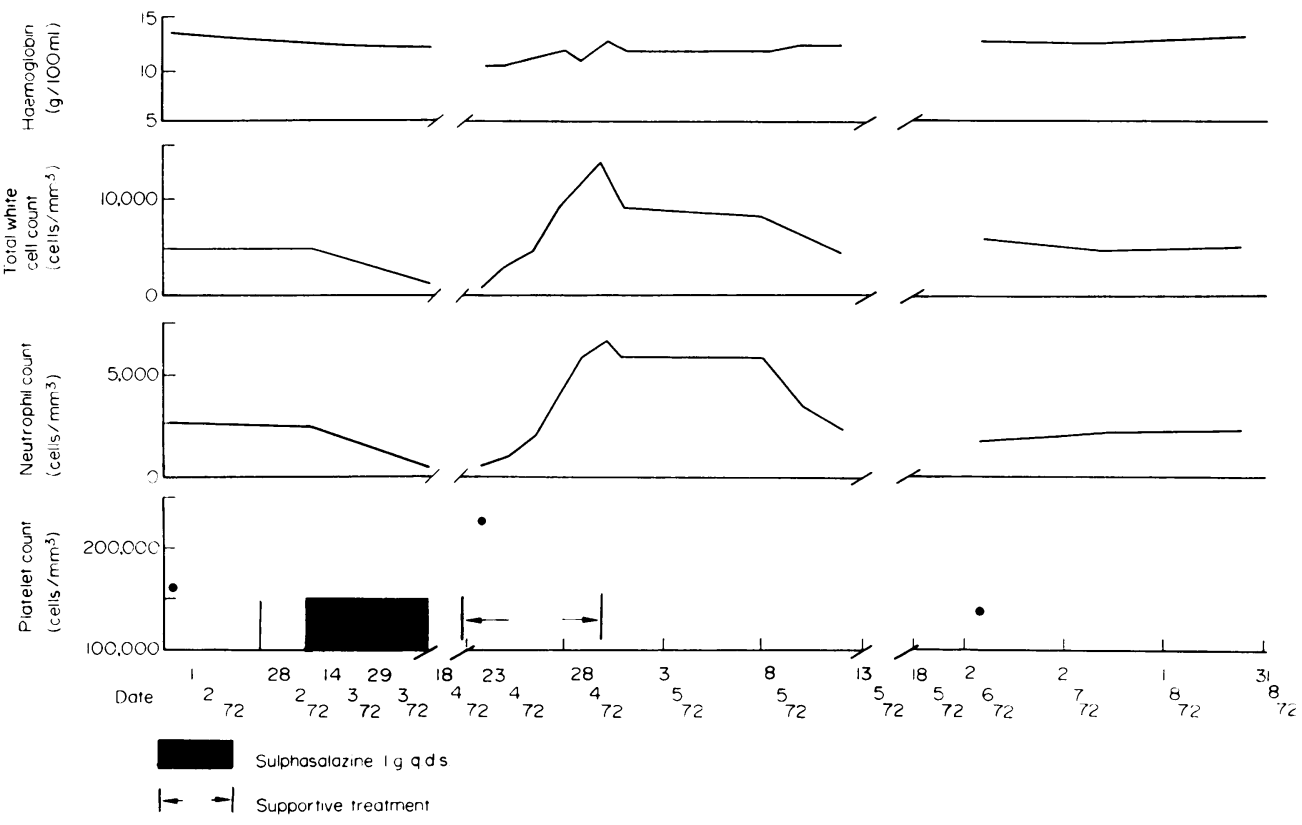

FIG. 2. Haematological parameters in a patient with agranulocytosis associated with sulphasalazine therapy. 
10 a.m., $7.34 \mu \mathrm{g} / \mathrm{ml} ; 12$ noon, $4.32 \mu \mathrm{g} / \mathrm{ml} ; \frac{1}{2}$ life $\left(T_{\frac{1}{2}}\right)=2.58 \mathrm{hr}$. Both intradermal and prick tests with a solution of sulphasalazine were negative. Protein immunophoresis showed a slightly raised $\operatorname{IgA}$ and a low IgM-IgG, $1150 \mathrm{mg} / 100 \mathrm{ml} ; \operatorname{IgA}, 400 \mathrm{mg} / 100$ $\mathrm{ml} ; \mathrm{IgM}, 55 \mathrm{mg} / 100 \mathrm{ml}$ IgD, $<5 \mathrm{mg} / 100 \mathrm{ml}$.

\section{Discussion}

In the assessment of severe drug reactions, one has to rely on probabilities that a particular drug is responsible, for definite proof requires re-challenging the patient with the drug, a procedure which is fraught with danger. It seems likely that sulphasalazine was responsible for the transient agranulocytosis described in this case report, as rapid recovery followed supportive therapy and withdrawal of the drug.

Agranulocytosis is a rare complication of sulphasalazine therapy, and up to 1968 only twenty cases had been recorded in the literature (Collins, 1968). In the present case the bone marrow feature of 'maturation arrest' presumably reflected a recovery phase. This appearance is believed to indicate a better prognosis than the finding of an aplastic marrow (De Gruchy, 1970). Previous reports showing a high mortality underline the seriousness of infection in these patients, and this was a feature of the present case.

The most frequent haematological complication of sulphasalazine therapy is Heinz body formation, which occurs in $8 \%$ of the patients treated with the drug (Bottinger et al., 1963), but Heinz body haemolytic anaemia and non-Heinz body haemolysis may rarely occur (Gardner \& Bargen, 1964). Although there was a slight fall in haemoglobin in the present case, no evidence of haemolysis was apparent. Thrombocytopenia (Thirkettle, Gough \& Read, 1963), methaemoglobinaemia and sulphaemoglobinaemia (Gardner \& Bargen, 1964) have also been noted with sulphasalazine treatment.

The mechanism of sulphasalazine induced agranulocytosis is uncertain. After absorption from the gut, sulphasalazine is deposited in connective tissue, where aminosalicylic acid and sulphapyridene are released. Sulphapyridene has long been recognized as one of the most toxic of the sulphonamides. It is possible that this toxic metabolite may cause agranulocytosis, either by depressing the production of granulocytes, or by increasing their peripheral destruction (Evans \& Ford, 1958). These workers studied a case of agranulocytosis associated with sulphasalazine therapy and concluded that an immune mechanism was responsible for the depression in production of granulocytes, for they demonstrated transient white cell agglutinins in the serum. In the present case, however, the absence of leucocyte antibodies, negative sulphasalazine skin tests and the minimal changes in protein immunophoresis would all argue against an immunological cause for the agranulocytosis. On the other hand, the patient was shown to be a 'slow' acetylator, and it is known that such individuals tend to have higher blood levels of the drug and suffer a greater incidence of minor side effects (Schroeder \& Evans, 1972). Thus a 'toxic' cause for the agranulocytosis seems more likely.

It would be of considerable interest to ascertain the acetylator status of patients who have had severe reactions to sulphasalazine. This information might be valuable in assessing the likelihood of patients with minor reactions subsequently suffering major complications.

This case has been reported to the Committee on Safety of Medicines.

\section{Acknowledgments}

We are grateful to Mr W. T. A. Donohoe, A.I.M.L.T., Department of Medicine, University of Liverpool, for undertaking the leucocyte antibody tests, and to Mr T. A. White, Ph.D., Nuffield Department of Medical Genetics, University of Liverpool, for completing the acetylation study. Dr J. A. Wilson, M.D., M.R.C.P., Consultant Allergist, United Liverpool Hospitals, kindly performed the sulphasalazine skin testing.

\section{References}

Botringer, L.E., EngSTedt, L., LAgercrantz, R. \& NyBERG, A. (1963) The occurrence of Heinz-bodies during Azulfidine treatment of ulcerative colitis. Gastroenterologia, $100,33$.

Collins, J.R. (1968) Adverse reactions to salicylazosulfapyridene (Azulfidine) in the treatment of ulcerative colitis. Journal of the Southern Medical Association, 61, 354.

DE Gruchy, G.C. (1970) In: Clinical Haematology in Medical Practice, 3rd edn, p. 380. Blackwell Scientific Publications, Oxford.

Evans, R.S. \& FORD, W.P. (1958) Studies of the bone marrow in immunological granulocytopenia following administration of salicylazosulfapyridene. Archives of Internal Medicine, 101, 244.

EvaNS, D.A.P. \& WHITE, T.A. (1964) Human acetylation polymorphism. Journal of Laboratory and Clinical Medicine, 63, 394.

GARDNER, M.D. \& BARgen, J.A. (1964) Hemolytic anemia secondary to salicylazosulfapyridene therapy. Journal of the American Medical Association, 190, 71.

LenNard-Jones, J.E., LONGmore, A.J., Newell, A.C., Wilson, C.W.E. \& Jones, F.A. (1960) An assessment of prednisone, salazopyrin, and topical hydrocortisone hemisuccinate used as out-patient treatment for ulcerative colitis. Gut, 1, 217.

Misiewicz, J.J., Lennard-Jones, J.E., Connell, A.M., BARON, J.H. \& JONES, F.A. (1965) Controlled trial of sulphasalazine in maintenance therapy for ulcerative colitis. Lancet, i, 185.

SCHROEDER, H. (1972) Simplified method for determining acetylator phenotype. British Medical Journal, 3, 506. 
Schroeder, H. \& Evans, D.A.P. (1972) Acetylator phenotype and adverse effects of sulphasalazine in healthy subjects. Gut, 13, 278.

SvarTZ, N. (1942) Salazopyrin, a new sulfanilimide preparation. A. Therapeutic results in aneumatic polyarthritis. B. Therapeutic results in ulcerative colitis. C. Toxic manifestations in treatment with sulfanilimide preparations. Acta medica scandinavica, 110, 577.
Terasuki, P.I. \& McClennand, J.D. (1964) Microdroplet assay of human serum cytotoxins. Nature, 204, 998.

Thirkettle, J.L., Gough, K.R. \& ReAD, A.E. (1963)c Agranulocytosis associated with sulphasalazine ('Salazopyrin') therapy. Lancet, i, 1395.

WALFORD, R.L. (1960) In: Leukocyte Antigens and Anti-O bodies, p. 116. Grune and Stratton, New York and London. 